University of Wollongong

Research Online

Faculty of Social Sciences - Papers (Archive) Faculty of Arts, Social Sciences \& Humanities

2016

Correlates of children's objectively measured physical activity and sedentary behavior in early childhood education and care services: A systematic review

Karen Tonge

University of Wollongong, klt186@uowmail.edu.au

Rachel A. Jones

University of Wollongong, rachelj@uow.edu.au

Anthony D. Okely

University of Wollongong, tokely@uow.edu.au

Follow this and additional works at: https://ro.uow.edu.au/sspapers

Part of the Education Commons, and the Social and Behavioral Sciences Commons

Research Online is the open access institutional repository for the University of Wollongong. For further information contact the UOW Library: research-pubs@uow.edu.au 


\title{
Correlates of children's objectively measured physical activity and sedentary behavior in early childhood education and care services: A systematic review
}

\begin{abstract}
Objective: To systematically review the correlates of physical activity and sedentary behavior among children in Early Childhood Education and Care (ECEC) services. Appropriate levels of physical activity and sedentary behavior are important to promote in ECEC services. Methods: A systematic search of 8 databases identified 27 studies published between 1992 and 2015 that met the inclusion criteria. The data were collected and analyzed in 2014 and 2015, and variables were categorized using a Social Ecological Framework. Results: Sixty-six variables were identified. The domains of child characteristics (18 studies) and physical environmental factors (17 studies) were most consistently studied, and, for physical activity had the most positive associations. The strongest associations of physical activity were: child's sex and age, children's gross motor coordination, provision of active opportunities for physical activity, and features of outdoor environments (size, use of and presence). The only strong association for sedentary behavior was the presence of outdoor environments. Conclusion: The correlates of physical activity and sedentary behavior in ECEC services vary. It appears that the most significant influence from within these settings is the physical environments for both physical activity and sedentary behavior. There was an absence of consistent evidence at the educator and organizational levels. Further research in this area should focus on effective use of space, intentional teaching opportunities and well as professional development for educators with an emphasis on their role as a facilitator of quality experiences.
\end{abstract}

\section{Keywords}

correlates, behavior, children, early, childhood, education, care, services, systematic, review, objectively, measured, physical, activity, sedentary

\section{Disciplines}

Education | Social and Behavioral Sciences

\section{Publication Details}

Tonge, K. L., Jones, R. A. \& Okely, A. D. (2016). Correlates of children's objectively measured physical activity and sedentary behavior in early childhood education and care services: A systematic review. Preventive Medicine, 89 129-139. 


\section{Title Page}

Title Correlates of Children's Objectively Measured Physical Activity and Sedentary Behavior in Early Childhood Education and Care Services: a Systematic Review.

\section{Authors and Affiliations}

Karen L Tonge $^{\mathrm{a}} \quad$ Dr Rachel A Jones ${ }^{\mathrm{a}} \quad$ Prof Anthony D Okely ${ }^{\mathrm{a}}$

${ }^{a}$ Early Start Research Institute, Faculty of Social Sciences, University of Wollongong, NSW, Australia

ktonge@uow.edu.au

rachelj@uow.edu.au

tokely@uow.edu.au

\section{Corresponding Author}

Karen Tonge

Early Start Research Institute (ESRI)

School of Education, Faculty of Social Sciences, Building 21

University of Wollongong NSW 2522 Australia

$6242214951 \quad$ ktonge@uow.edu.au

Word Count $\quad$ Words- Abstract $242 \quad$ Text 4392

Pages- 37 Tables- $4 \quad$ Figures- $1 \quad$ Checklist (PRISMA) - 1

Conflict of Interest Statement No conflict of interest

Financial Disclosure $\quad$ No financial disclosures were reported by the authors of this paper. 


\begin{abstract}
Objective: To systematically review the correlates of physical activity and sedentary behavior among children in Early Childhood Education and Care (ECEC) services. Appropriate levels of physical activity and sedentary behavior are important to promote in ECEC services.

Methods: A systematic search of 8 databases identified 27 studies published between 1992 and 2015 that met the inclusion criteria. The data were collected and analyzed in 2014 and 2015, and variables were categorized using a Social Ecological Framework.

Results: Sixty-six variables were identified. The domains of child characteristics (18 studies) and physical environmental factors (17 studies) were most consistently studied, and, for physical activity had the most positive associations. The strongest associations of physical activity were: child's sex and age, children's gross motor coordination, provision of active opportunities for physical activity, and features of outdoor environments (size, use of and presence). The only strong association for sedentary behavior was the presence of outdoor environments.

Conclusion: The correlates of physical activity and sedentary behavior in ECEC services vary. It appears that the most significant influence from within these settings is the physical environments for both physical activity and sedentary behavior. There was an absence of consistent evidence at the educator and organizational levels. Further research in this area should focus on effective use of space, intentional teaching opportunities and well as professional development for educators with an emphasis on their role as a facilitator of quality experiences.
\end{abstract}

This review has been registered with Prospero, \#CRD42014013660.

\title{
Key words
}

Childcare; Preschool; Physical activity; Sedentary behavior; Social ecological framework; Correlates 


\section{Introduction}

Children's health and well-being are paramount to ensure optimum learning and development (DEEWR, 2009). Physical well-being allows children to be physically active and active children have improved blood pressure, cholesterol and bone density, emotional and cognitive development, self-esteem, and social interaction skills compared with less active children (Copeland et al., 2012; Timmons et al., 2012; Lewicka and Farrell, 2007). Active experiences support children to become 'physically literate', which is the foundation of physical activity experiences for later years (Maude, 2008).

The period of early childhood (birth to 5 years) is critical for establishing health, well-being and healthy behaviors (Ward et al., 2012). It is a time of rapid growth in young children, including significant brain development (Shonkoff, 2013), physical and social development, as well as the formation of behaviour patterns. It is a time of significant opportunity, yet one of considerable risk, and that quality experiences are crucial as an investment in children's health and well-being (Shonkoff, 2013). Social and physical environments have an important influence (Brown et al., 2009), and quality experiences provide opportunities for children to learn from significant others, as well as practice skills that will lead to better immediate and long term health and education outcomes (Shonkoff, 2013; Melhuish et al., 2008).

The nature and scale of Early Childhood Education and Care (ECEC) services have changed dramatically in most developed countries in the last two decades according to the OECD (Organization for Economic Co-operation and Development). In western Europe for example there has been an increase in children attending ECEC from 20\% to $90 \%$ over a $15-20$ year period from 1994 to 2014 (OECD, 2014). With enrollment rates high, the ability of ECEC service programs to influence many children's learning, development and behaviors in a way that will promote good health across their life spans (Ward et al., 2009) is significant. ECEC services can provide social and physical environments that support quality experiences, learning and development through offering structured and unstructured experiences (Ward et al., 2010), including physical activity experiences. A number of physical activity interventions that have focused on modifying the social and physical environment have been implemented in ECEC services (Gordon et al., 2013) however results have been inconsistent. For example Cardon et al. (2008) reported no significant changes in physical activity levels following implementation of an intervention that focus on the physical environmental, while 
Hannon and Brown (2008) reported significant changes in light-, moderate- and vigorousintensity physical activity following their intervention that also focused on modifications to the physical environment. Recommendations from recent reviews (Gordon et al., 2013) suggest that further understanding of the ECEC environment and factors in these services that influence physical activity and sedentary behavior is required.

Reviews have addressed the correlates of children's physical activity (Hinkley et al., 2008) and sedentary behavior (Hinkley et al., 2010), yet to the best of our knowledge, no reviews have specifically identified correlates within ECEC services. Identifying influences on physical activity and sedentary behavior in ECEC services is particularly important for the development of evidence-guided programs and interventions (Hinkley et al., 2008). Therefore the aim of this systematic review was to identify these influences. Consistent with other reviews of correlates of physical activity in children and adults (Ridgers et al., 2012; Hinkley et al., 2010; Hinkley et al., 2008; Sallis et al., 2000) a social ecological framework was used to scaffold the variables identified in this review. An ecological model will allow for the investigation of multidimensional factors that influence physical activity and sedentary behavior and the bidirectional relationships among these factors as well as the investigation of how factors at one level moderate the influence of factors from another level (Kearns, 2010).

\section{Methods}

The process and reporting of this review adhered to the guidelines outlined in the Preferred Reporting Items for Systematic Reviews and Meta-analysis (PRISMA) statement (Moher et al., 2009).

\subsection{Search Strategy}

A literature search of papers was conducted in eight electronic databases - ERIC, SPORT Discus, MEDLINE, Education Research Complete, Scopus, A+ Education, PsychINFO and PubMed. The databases were searched from their creation until April 2015. The search was conducted using the search terms physical activity OR movement AND preschool OR childcare OR daycare OR nursery OR pre-K AND correlate OR factor OR influence OR predictor. A similar search was conducted for sedentary behavior and used the following terms sedentary behavior OR sitting AND preschool OR childcare OR daycare OR nursery 
OR pre-K AND correlate OR factor OR influence OR predictor. Duplicates from these searches were then removed (KT). Titles were then screened (KT, RJ, AO) and following this abstracts and full articles were reviewed (KT, RJ) and checked if there was a discrepancy (AO). Manual searches of reference lists were also completed, and experts in the field were consulted (KT). Data were collected and analysed in 2014 and 2015. This extensive process of selection was similar to that described in a number of other systematic reviews (Ridgers et al., 2012; Hinkley et al., 2008; Sallis et al., 2000).

\subsection{Inclusion and exclusion criteria}

Papers were included if they: (1) were peer reviewed, written in English and available in full text, (2) included data from an ECEC service (birth-5years) setting, and (3) were a quantitative study that used an objective measure (such as accelerometers or OSRAP) of physical activity and/or sedentary behaviors. Pilot and mixed methodology studies were included if they met these criteria. Studies that measured habitual physical activity were included if physical activity and sedentary behavior data during ECEC hours were reported separately. Intervention studies were excluded as the interventions did not report associations.

\subsection{Data extraction and synthesis}

Information extracted from each article included: the sample (age range of children, number of ECEC services, number of children), physical activity/sedentary behavior assessment and outcome (method(s) of data collection, level of physical activity and/or sedentary behavior assessed), and correlates of physical activity and sedentary behavior (eg boys were more active than girls, older children more active). Researchers (KT, RJ, AO) then categorised these correlates into the associated social ecological framework (Kearns, 2010) domain (Child, Educator, Physical Environmental and/or Organizational) (see Table 2). A variety of techniques were used in the selected papers to report variables including univariate, bivariate and multilevel analyses. . Similar to another review (Ridgers et al., 2012), for analyses focused on correlates where multiple analytic models were reported, findings from the most advanced, fully-adjusted model were extracted (Hinkley et al., 2010).

All variables were recorded in the tables. Those that were reported a statistically significant $(\mathrm{p}<0.05)$ association with physical activity and/or sedentary behavior were coded as + or -, 
depending on the association (column 3, Tables 3 and 4) and those that were not significant were recorded in column 4, Tables 3 and 4 . The number of studies reporting the same association was tallied and then this 'tally' was converted to a percentage. Some studies reported multiple variables (such as child age in relation to indoor as well as outdoor environments). In these instances, the reference was included multiple times in the association column (Table $3 \& 4$ ) and the specific variable measured indicated with a footnote (Ridgers et al., 2012). These codes were then analysed and given a summary code for association (see Table 1) based upon the percentage of studies and the direction of the association. This method of coding has been used previously (Ridgers et al., 2012; Hinkley et al., 2010; Hinkley et al., 2008; Sallis et al., 2000).

Insert Table 1about here

\section{Results}

\subsection{Summarising the articles}

A total of 3771 papers were retrieved with 27 studies meeting inclusion criteria (Figure 1 \& Table 2). More than half the studies (56\%) were conducted in the U.S. ( $n=15)$ (Pate et al., 2014; Stephens et al., 2014; Byun et al., 2013; Shen et al., 2013; Raustorp et al., 2012; Robinson et al., 2012; Nicaise et al., 2011; Dowda et al., 2009; Williams et al,. 2008; Pate et al., 2008; Bower et al., 2008; Dowda et al., 2004; Pate et al., 2004; Trost et al., 2003; McKenzie et al., 1992), with the remaining conducted in Canada (n=3) (Vanderloo et al., 2014; Vanderloo et al., 2013; Gagne \& Harnois, 2013), Sweden (n=3) (Raustorp et al., 2012; Pagels et al., 2011; Boldemann et al., 2006;), Netherlands (n=2) (Gubbels et al., 2012; Gubbels et al., 2011), Belgium (n=2) (Van Cauwenberghe et al., 2012; Cardon et al., 2008), Denmark (n=2) (Olesen et al., 2013; Grontved et al., 2009), and Australia ( $n=1$ ) (Sugiyama et al., 2011). One study collected data across countries - Sweden and the U.S (Raustorp et al., 2012). Physical activity and sedentary behaviors were assessed using accelerometers ( $n=17)$ (Pate et al., 2014; Stephens et al., 2014; Vanderloo et al., 2014; Byun et al., 2013; Gagne \& Harnois, 2013; Olesen et al., 2013; Shen et al., 2013; Vanderloo et al., 2013; Raustorp et al., 2012; Van Cauwenberghe et al., 2012; Pagels et al., 2011; Sugiyama et al., 2011; Dowda et al., 2009; Grontved et al., 2009; Williams et al., 2008; Pate et al., 2004; Trost et al., 2003), 
direct observation (OSRAP (n=8) (Gubbels et al., 2012; Gubbels et al., 2011; Nicaise et al., 2011; Dowda et al., 2009; Pate et al., 2008; Bower et al., 2007; Dowda et al., 2004; Trost et al., 2003), BEACHES ( $n=1$ ) (McKenzie et al., 1992), SOFIT ( $n=1)(\operatorname{Van}$ Cauwenberghe et al., 2012)) and pedometers ( $n=4)$ (Robinson et al., 2012; Pagels et al., 2011; Cardon et al., 2008;

Boldemann et al., 2006) . Five studies used multiple objective methods of measuring physical activity and sedentary behaviour (Van Cauwneberghe et al., 2012; Pagels et al., 2011; Dowda et al., 2009; Trost et al., 2003; McKenzie et al., 1992), for example OSRAP as well as accelerometers (Trost et al., 2003). Of the 27 studies included, most (74\%) reported moderate- to vigorous-intensity physical activity (MVPA) (Pate et al., 2014; Stephens et al., 2014; Vanderloo et al., 2014; Olesen et al., 2013; Shen et al., 2013; Vanderloo et al., 2013; Raustorp et al., 2012; Van Cauwenberghe et al., 2012; Nicaise et al., 2011; Pagels et al., 2011; Sugiyama et al., 2011; Dowda et al., 2009; Grontved et al., 2009; Bower et al., 2008; Pate et al., 2008; Williams et al., 2008; Dowda et al., 2004; Pate et al., 2004; Trost et al., 2003; McKenzie et al., 1992), and many (56\%) reported total physical activity (TPA) (Pate et al., 2014; Vanderloo et al., 2014; Gagne \& Harnois, 2013; Vanderloo et al., 2013; Gubbels et al., 2012; Robinson et al., 2012; Gubbels et al., 2011; Pagels et al., 2011; Bower et al., 2008; Cardon et al., 2008; Pate et al., 2008; Boldemann et al., 2006; Trost et al., 2003; McKenzie et al., 1992). Sedentary behavior was reported in thirteen studies (48\%) (Vanderloo et al., 2014; Byun et al., 2013; Vanderloo et al., 2013; Raustorp et al., 2012; Nicaise et al., 2011; Pagels et al., 2011; Sugiyama et al., 2011; Dowda et al., 2009; Pate et al., 2008; Williams et al., 2008; Bower et al., 2007; Dowda et al., 2004; Pate et al., 2004) (Table 2).

Sixty-six physical activity and sedentary behavior correlates were identified (Tables 3 \& 4), of which 13 were classified as child variables, ten classified as educator variables, 21 classified as physical environmental and 22 classified as organizational variables. Associations identified (Table 3 \& 4) reflect the relationship between the correlate and children's total physical activity (light, moderate and vigorous) and sedentary time while in the ECEC service, within a range of environments (indoor, outdoor, structured, unstructured), unless noted otherwise.

Insert Figure 1about here

Insert Table 2about here 
Insert Table 3about here

Insert Table 4about here

\subsection{Summarising the outcome findings}

\subsubsection{Child Variables}

Nine child correlates were identified (Tables 3 \& 4). The most frequent individual correlate reported was sex $(n=18)$, with boys being more physically active than girls. Strong positive associations (4 or more studies) with children's physical activity in ECEC services were found for age and motor coordination, older children were more active than younger children (6 out of 9 studies) (Gagne \& Harnois, 2013; Gubbels et al., 2012; Gubbels et al., 2011; Pagels et al., 2011; Grontved et al., 2009; Boldemann et al., 2006) and better motor coordination was positively related to physical activity (3 out of 4 studies) (Olesen et al., 2013; Robinson et al., 2012; Williams et al., 2008).

\subsubsection{Educator Variables}

Educator variables included individual characteristics such as qualifications, training, attitudes and practices.

Of the 27 studies, educator variables were the least studied. Eight variables were reported from 13 references (Tables 3 \& 4). Of the variables identified, none reported a strong association, and only educator behaviors (ie, prompts and feedback (Vanderloo et al., 2014; Gagne \& Harnois, 2013; Van Cauwenberghe et al., 2012; Gubbels et al., 2011; Dowda et al., 2009; Bower et al., 2007; Boldemann et al., 2006)), educator qualification and training (Van Cauwenberghe et al., 2012; Nicaise et al., 2011; Sugiyama et al., 2011; Dowda et al., 2009; Bower et al., 2008; Cardon et al., 2008; Dowda et al., 2004) and educator presence (Gubbels 
et al., 2011; Nicaise et al., 2011; Sugiyama et al., 2011; Cardon et al., 2008) were reported four or more times, all with inconclusive results.

\subsubsection{Physical Environmental Variables}

Physical environmental variables were the most frequently reported domain of children's physical activity and sedentary behavior in ECEC services, with 12 variables identified (Tables 3 \& 4). Strong positive associations were reported between physical activity and outdoor environments (eg, the opportunities for children to play in these) and the size of the play space. Outdoor environments were associated with increased children's physical activity

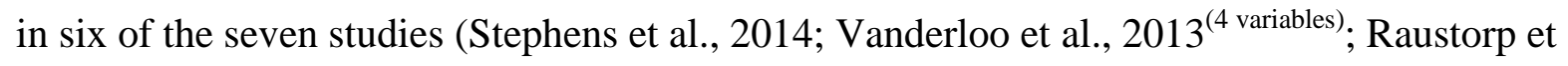
al., 2012), and reduced sedentary behavior in three of the four studies (Vanderloo et al., 2013 (2 variables); Pate et al., 2004). It was only with girls’ MVPA that there was no association for both physical activity and sedentary behavior in outdoor environments (Vanderloo et al., 2013). The size of the play space was associated in four of the seven studies (Gubbels et al., 2011; Nicaise et al., 2011; Dowda et al., 2009; Boldemann et al., 2006) with larger play spaces (eg total area, $\mathrm{m}^{2}$ ) related to higher levels of physical activity.

\subsubsection{Organizational Variables}

Ten organizational variables were reported (Tables 3 \& 4). Active opportunities, service quality (eg, as rated by the EPAO, ECERS-R), preschool location and group size were all identified five or more times, with only active opportunities showing strong positive associations with children's physical activity, which included a shorter recess (play time) (Cardon et al., 2008). Policy was discussed in two studies (Olesen et al., 2013; Bower et al., 2008) both no association with physical activity or sedentary behavior was identified.

\section{Discussion}

This is the first known review that reports the correlates of physical activity and sedentary behavior in ECEC services. It is warranted given that the majority of children aged 3-5 years attend ECEC services (OECD, 2014) and ECEC services have a critical role in providing opportunities for children to be physically active. Similar to other reviews on children's physical activity and sedentary behavior, this review showed that correlates of children's 
physical activity and sedentary behavior with ECECs are multi-dimensional (Hinkley et al., 2010; Hinkley et al., 2008; Sallis et al., 2000). A greater number of physical activity correlates were identified compared with sedentary behavior correlates, and consistent with a review on correlates of physical activity during school recess time (Ridgers et al., 2012), the majority of variables identified in this review were at the child and physical environmental levels of the social ecological framework. Even though many variables were identified at the child level, this review has primarily focused on the more modifiable influences of children's physical activity and sedentary behaviour within an ECEC service, such as routines and opportunities for physical activity experiences. Discussions of child characteristics are abbreviated as the child variables have been addressed in other reviews (Timmons et al., 2012; Hinkley et al., 2008) and this systematic review primarily focuses on factors associated within ECEC services.

The child domain provided evidence that boys were active than girls, which is consistent with other reviews (Ridgers et al., 2012; Sallis et al., 2000), that older children were more active than younger children, as were children with better motor coordination. A reason for these results in an ECEC environment may be the programs and environments that are offered to children. Even though sex and age are not modifiable characteristics, it is important for programs and social and physical environments, which are modifiable aspects, to be designed to provide opportunities for all children to improve skills and increase physical activity. Given that educators within the ECEC environment are responsible for providing experiences for children, it is plausible to suggest that they may need to provide more intentional opportunities for children from the identified groups, such as for girls to engage in active play (Morgan et al., 2013), and programs and environments that engage younger children and children with less developed motor skills. These may increase children's motivation and involvement in physical activity, even at this young age.

Educators were included in this review as a specific domain as they are an important aspect of ECEC service pedagogy. Less than 50\% (12 from 27) of the studies and only 12\% (8 from 66) of the variables were in the educator domain and none of these reported strong associations with physical activity or sedentary behavior. Although educator variables were the least represented in the 27 studies in this review, several correlates were identified, including: educators being present (Gubbels et al., 2011; Nicaise et al., 2011; Sugiyama et al., 2011; Cardon et al., 2008) and educator training and qualifications (Van Cauwenberghe et al., 
2012; Nicaise et al., 2011; Sugiyama et al., 2011; Dowda et al., 2009; Bower et al., 2008; Cardon et al., 2008; Dowda et al., 2004). While educator involvement, creativity during physically active play, and modelling have been suggested as strategies to promote children's physical activity and reduce sedentary behaviors (Tandon et al., 2015; Dwyer et al., 2008; Irwin et al., 2005), we found no studies in ECEC settings that assess these associations. Due to the few educator variables reported, it is difficult to draw conclusions in this domain and given the role of the educator within the ECEC environment, a greater number of studies investigating these variables are needed. Specifically, active involvement and engagement of educators are potentially important factors in increasing children's physical activity and reducing sedentary behaviors (Tandon et al., 2015; Hodges et al., 2013), as is evident in a study of home environments (Hesketh et al., 2014), which showed associations between the physical activity of mothers and their 4 year old children. In the absence of studies in this area in ECEC settings, this warrants further studies in the relationship between the physical activity and sedentary behaviors of educators and children.

In the physical environmental domain, this review presented two variables with strong positive associations - the presence of an outdoor environment and larger play spaces. Both were conducive to higher levels of physical activity and conversely outdoor environments were positively associated with reduced sedentary behaviors. Reasons for the presence of an outdoor environment influencing physical activity maybe that outdoor environments afford opportunities for children to engage in activities that may not be present within indoor settings, such as equipment more conducive to gross motor experiences, as well as varying surfaces and natural features that may promote more active play. This result is consistent with another study that indicated that the outdoor environment supports children's active play opportunities (Tandon et al., 2015) yet other studies conclude that the presence of outdoor environments for physical activity may not be as important as once thought, but rather it is the equipment available that had a more influential role (Dowda et al., 2009; Hannon and Brown, 2008; Alhassan et al., 2007). The reason that the size of the outdoor environment, such as larger play spaces has also reported a positive influence on increasing children’s physical activity may be that access to spacious environments provide opportunities for children to move more freely and may result in the need for greater movement between experiences, an aspect of environmental design which is an area of ongoing research (Boldemann et al., 2006). Together, the presence of outdoor environments, and the influence of the size of these 
environments provides evidence of the significance of appropriately designed ECEC services and programs that offer sufficient opportunities for play in outdoor spaces (Sallis et al., 2000).

Interestingly, multiple aspects of the physical environmental domain presented either no association or an inconclusive result: sedentary items (eg the presence of TV, computers), natural features / surface (eg gardens, the type of surface), indoor environments, gradient (eg, the presence of hills), shade, markings (eg bike tracks), portable equipment, fixed equipment, height of equipment and weather conditions. These inconclusive results may be due to the wide range of variables identified, and is in contrast to other reviews (Hodges et al., 2013; Dyment et al., 2009) that have suggested that these factors are important.

The organizational domain primarily found little to no association with physical activity or sedentary behavior. The only strong positive association with physical activity was the provision of active opportunities which included structured physical activity, the facilitation of a specific indoor space for physical activity and planned recess times (Shen et al., 2013; Dowda et al., 2009; Bower et al., 2008; Cardon et al., 2008). Reasons for this could be the range of variables presented in this domain, and the variability within each, such as specific aspects of the program including field trips, preschool type, group size, and the use of electronic media. As discussed, in the physical environmental domain the greatest physical activity occurs outside (Van Cauwenberghe et al., 2012; Pate et al., 2004) however the findings in the organizational domain show that the way an indoor environment is used has been shown to be related to physical activity (such as having a specific space for physical activity) (Sugiyama et al., 2011). Therefore to maximise opportunities for increasing physical activity and reducing sedentary behavior, it is important for educators also to consider how they can most effectively use the inside environment for physical activity and reducing sedentary behavior. Reducing children’s sitting time inside (Sugiyama et al., 2011) and incorporating more movement activities (Archer \& Siraj, 2014) into learning experiences are modifiable aspects of ECEC services and may have positive benefits for children's physical activity.

It is interesting to note that in the organizational domain, the actual period of time spent outside has no association with children's physical activity and in particular with children's MVPA (Dowda et al., 2009; Dowda et al., 2004).This is important for the ECEC sector as it appears to be the quality, rather than the quantity of the play time that is significant. This view 
is supported by another study that reports that additional outdoor playtime is inversely related to children's physical activity levels (Alhassan et al., 2007). Consistent with another study (Sallis et al., 2000), the findings related to opportunities for physical activity validate the need for well-designed, intentional environments and programs to support physical activity, and also align with a qualitative study (Tucker et al., 2011) which suggests educators felt that additional training and resources were key areas to increase children's physical activity and reduce sedentary behaviors. Providing these opportunities should be a goal of directors, educators and policy developers. Adopting written policies, in conjunction with existing programs that support frameworks and curriculum may increase children's daily physical activity and the attainment of daily recommendations.

\subsection{Strengths \& Limitations}

This review has a number of strengths: (1) alignment with the PRISMA statement for reporting systematic reviews (Moher et al., 2009) thereby providing precision and structure;

(2) reviews studies that used objective measures of physical activity and sedentary behavior;

(3) included correlates that have not been specifically studied before in ECEC settings; and

(4) follows a social ecological framework, which provided a clear organization of the reporting and analysis, relevant to an ECEC service.

However the results of this review should be considered in light of a number of limitations, including: (1) there were only a small number of studies for some variables. Of significance is that less than a third of the variables identified were investigated four or more times and less than $30 \%$ of the studies examined correlates across all levels of the model simultaneously, (2) most of the studies were from the U.S and therefore may limit the generalizability of the results, (3) the search was limited to studies in the English language, (4) the studies reviewed included varied in sample size (2-63 ECEC services and 34-783 children) and methodologies (although all used an objective measure of physical activity and /or sedentary behavior), which may potentially impact the heterogeneity of the estimates, and the likelihood of biases in the overall conclusion. This variability seen in the papers reviewed is similar to previous reviews (Hodges et al., 2013; Ridgers et al., 2012) and is expected given the diversity within the ECEC sector. Furthermore, the range of methods of assessing physical activity and sedentary behavior may have influenced the associations identified, which is consistent with 
other reviews (Hodges et al., 2013; Ridgers et al., 2012; Hinkley et al., 2010). It is crucial that future studies focus on consistently using the most objective measures of physical activity and sedentary behavior to increase comparability of study results, (5) the social ecological framework is a complex framework and the potential interactions between the various domains may have consequences on the outcome measures (investigating such interactions was beyond the scope of this review), and (6) some variables explored have presented conflicting positive and negative associations (for example Educator Behaviors in Table 3), this is not factored into the coding approach adopted. An alternate approach to 'tallying' the scores maybe more appropriate in future reviews.

\section{Conclusion}

The early years are a significant time for children, and ECEC services are in a crucial position to promote and encourage learning and development, as well as healthy behaviors (Riethmuller et al., 2010). This systematic review explored the correlates of physical activity and sedentary behavior in ECEC services.

In summary, this review shows that the influences upon children's physical activity and sedentary behavior in ECEC settings are multidimensional. Educators have a critical role in promoting physical activity and reducing sedentary time, and have opportunities to support children's activity levels across many of the domains in the social ecological framework. This review will inform ECEC practice as it highlights capacities for increasing physical activity, such as the effective use of space, time and intentional teaching opportunities. Professional development for educators that focuses on these aspects within an ECEC service, as well as an emphasis on their role as a facilitator/educator of quality experiences is warranted. Further research and intervention is needed to ensure children have access to rich environments, knowledgeable and involved educators, as well as quality interventions and programs that are most conducive to engaging children in levels of physical activity for health and well-being in early childhood and beyond.

\section{Conflict of Interest Statement}

The authors declare that there are no conflicts of interest. 


\section{References}

References included in the Systematic Review are marked with *

Alhassan S, Sirard JR, Robinson TN. The effects of increasing outdoor play time on physical activity in Latino preschool children. Int J Pediatr Obes. 2007;2(3):153-158. doi:10.1080/17477160701520108

Archer C, Siraj I. Measuring the quality of movement-play in early childhood education settings: Linking movement-play and neuroscience. European Early Childhood Education Research Journal. 2014:1-22. doi:10.1080/1350293X.2014.890351

* Boldemann C, Blennow M, Dal H, et al. Impact of preschool environment upon children's physical activity and sun exposure. Prev Med. 2006;42(4):301-308. doi:10.1016/j.ypmed.2005.12.006

* Bower JK, Hales DP, Tate DF, Rubin DA, Benjamin SE, Ward DS. The childcare environment and children’s physical activity. Am J Prev Med. 2008;34(1):23-29. doi:10.1016/j.amepre.2007.09.022

Brown, WH, Pfieffer, KA, McIver, KL, Dowda, M, Addy, CL, Pate, RR. Social and environmental factors associated with pre-schoolers non sedentary physical activity. Child Dev. 2009;80(1):45-58.

* Byun W, Blair SN, Pate RR. Objectively measured sedentary behavior in preschool children: comparison between Montessori and traditional preschools. Int J Behav Nutr Phys Act. 2013;10(2). doi:10.1186/1479-5868-10-2

Cardon G, Labarque V, Smits D, De Bourdeaudhuij I. Promoting physical activity at the preschool playground: The effects of providing markings and play equipment. Prev Med, 2009: 48, 335-340. doi:10.1016/j.ypmed.2009.02.013

* Cardon G, Van Cauwenberghe E, Labarque V, Haerens L, De Bourdeaudhuij I. The contribution of preschool playground factors in explaining children's physical activity during recess. Int J Behav Nutr Phys Act. 2008;5(1):11.doi:10.1186/1479-5868-5-11

Copeland KA, Kendeigh CA, Saelens BE, Kalkwarf HJ, Sherman SN. Physical activity in child-care centers: do teachers hold the key to the playground? Health Educ Res. 2012;27(1):81-100. doi:10.1093/her/cyr038

DEEWR, Australian Government Department of Education, Employment and Workplace Relations for the Council of Australian Governments. Belonging, Being, Becoming. The Early Years Learning Framework for Australia. Commonwealth of Australia. 2009. 
* Dowda M, Brown WH, McIver KL, et al. Policies and characteristics of the preschool environment and physical activity of young children. Pediatrics, 2009;123(2), e261-266. doi:10.1542/peds.2008-2498

* Dowda M, Pate RR, Trost SG, Almeida MJ, Sirard JR. Influences of preschool policies and practices on children's physical activity. Journal of Community Health, 2004;29(3):183196.

Dyment JE, Bell AC, Lucas AJ. The relationship between school ground design and intensity of physical activity. Child Geogr. 2009;7(3): 261-276. doi:10.1080/14733280903024423

* Gagne C, Harnois I. The contribution of psychosocial variables in explaining preschoolers' physical activity. Health Psycho., 2013;32(6);657-665.

Gordon E, Tucker P, Shauna B, Carron AV. Effectiveness of Physical Activity Interventions for Preschoolers: A Meta-Analysis. Res Q Exerc Sport, 2013: 84, 287-294.

* Grontved A, Pedersen GS, Andersen LB, Kristensen PL, Moller NC, Froberg K. Personal characteristics and demographic factors associated with objectively measured physical activity in children attending preschool. Pediatric Exercise Science, 2009;21(2):209-219.

* Gubbels JS, Van Kann DH, Jansen MW. Play equipment, physical activity opportunities, and children's activity levels at childcare. Journal of Environmental \& Public Health, 2012(326520). doi:10.1155/2012/326520

* Gubbels JS, Kremers SP, van Kann DH, et al. Interaction between physical environment, social environment, and child characteristics in determining physical activity at child care. Health Psychol. 2011;30(1):84-90.doi:10.1037/a0021586

Hannon JC, Brown BB. Increasing preschoolers' physical activity intensities: An activityfriendly preschool playground intervention. Prev Med. 2008;46(6): 532-536. doi:10.1016/j.ypmed.2008.01.006

Hesketh KR, Goodfellow L, Ekelund U, McMinn AM, Godfrey KM, Inskip HM, Cooper C, Harvey NC, van Sluijs EMF. Activity levels in mothers and their preschool children. Pediatrics, 2014: 133(4), e973-e980. doi: 10.1542/peds.2013-3153.

Hinkley T, Salmon J, Okely AD, Trost SG. Correlates of sedentary behaviors in preschool children: A review. Int J Behav Nutr Phys Act. 2010;7(1):66-66.

Hinkley T, Crawford D, Salmon J, Okely AD, Hesketh, K. Preschool children and physical activity. A review of correlates. Am J Prev Med. 2008;34(5):435-441. doi:10.1016/j.amepre.2008.02.001

Irwin JD, He M, Bouck LM, Tucker P, Pollett GL. Preschoolers' physical activity behaviors: Parents' perspectives. Can J Public Health. 2005;96:299-303. 
Kearns K. Frameworks for learning and development. Frenchs Forest: Pearson; 2010.

Lewicka M, Farrell.L. Physical activity measurement in children 2-5 years of age. (Report No. CPAH06-002). Retrieved from NSW Centre for Physical Activity and Health website: http://www.researchgate.net/publication/242149714_Physical_Activity_Measurement_in Children_2-5_Years_of_Age. 2007

* McKenzie TL, Sallis JF, Nader PR, Broyles SL, Nelson JA. Anglo- and Mexican-American preschoolers at home and at recess: Activity patterns and environmental influences. $J$ Dev Behav Pediatr. 1992;13(3):173-180.

Maude P. How Do I do this Better? From Movement Development into Physical Literacy. In: Whitebread D, Coltman P, ed. Teaching and Learning in the Early Years. ${ }^{\text {rd }}$ ed. Oxon: Routledge; 2008:251-268.

Melhuish E, Belsky J, Leyland AH \& Barnes J. Effects of fully-established Sure Start local programmes on 3-year-old children and their families living in England: a quasiexperimental observational study. Lancet, 2008;372(9650):1641-1647.doi: 10.1016/S0140-6736(08)61687-6.

Moher D, Liberati A, Tetzlaff J, Altman DG. Preferred reporting items for systematic reviews and meta-analyses: the PRISMA statement. Ann Intern Med. 2009;151(4):264-269.

Morgan PJ, Barnett LM, Cliff DP, et al. Fundamental movement skill interventions in youth: A systematic review and meta-analysis. Pediatrics, 2013;132(5), E1361-E1383. doi:10.1542/peds.2013-1167

* Nicaise V, Kahan D, Sallis JF. Correlates of moderate-to-vigorous physical activity among preschoolers during unstructured outdoor play periods. Prev Med. 2011;53(4-5):309-315. doi:10.1016/j.ypmed.2011.08.018

OECD - Organization for Economic Cooperation and Development, Family database. (2014)PF3.2: Enrolment in childcare and pre-schools, OECD - Social Policy Division Directorate of Employment, Labour and Social Affairs.

* Olesen LG, Kristensen PL, Korsholm L, Froberg K. Physical Activity in Children Attending Preschools. Pediatrics, 2013;132(5):1310-1318.doi: 10.1542/peds.2012-3961

* Pagels P, Boldemann C, Raustorp A. Comparison of pedometer and accelerometer measures of physical activity during preschool time on 3- to 5-year-old children. Acta Paediatr. 2011;100(1):116-120. doi:10.1111/j.1651-2227.2010.01962.x

* Pate RR, O'Neill JR, Byun W, McIver KL, Dowda M, Brown WH. Physical activity in preschool children: comparison between Montessori and traditional preschools. J Sch Health. 2014;84(11):716-721. doi:10.1111/josh.12207 
* Pate RR, McIver K, Dowda M, Brown WH, Addy C. Directly observed physical activity levels in preschool children. J Sch Health. 2008;78(8):438-444. doi: 10.1111/j.17461561.2008.00327.x

* Pate RR, Pfeiffer KA, Trost SG, Ziegler P, Dowda M. Physical activity among children attending preschools. Pediatrics, 2004;114(5):1258-1263. doi:10.1542/peds.2003-1088.

* Raustorp A, Pagels P, Boldemann C, Cosco N, Soderstrom M, Martensson F. Accelerometer measured level of physical activity indoors and outdoors during preschool time in Sweden and the United States. J Phys Act Health. 2012;9(6):801-808.

Ridgers ND, Salmon J, Parish A-M, Stanley, RB, Okely AD. Physical activity during school recess. A systematic review. Am J Prev Med. 2012;43(3):320-328.

Riethmuller A, Jones R, Okely A. Efficacy of interventions to improve motor development in young children: A systematic review of controlled trials. Journal of Science and Medicine in Sport. 2010;12,e83-e83. doi:10.1016/j.jsams.2009.10.170

* Robinson LE, Wadsworth DD, Peoples CM. Correlates of school-day physical activity in preschool students. Res Q Exerc Sport. 2012;83(1):20-26.

Sallis JF, Prochaska JJ, Taylor WC. A review of correlates of physical activity of children and adolescents. Med Sci Sports Exerc. 2000;32(5):963-975. doi:10.1097/00005768200005000-00014

* Shen B, Alexander G, Milberger S, Jen K-L. An exploratory study of seasonality and preschoolers' physical activity engagement. J Phys Act Health. 2013;10(7):993-999.

Shonkoff JP. Changing the narrative for early childhood investment. JAMA Pediatrics. 2014;168(2):105-106. doi:10.1001/jamapediatrics.2013.4212

* Stephens RL, Xu Y, Lesesne CA, et al. Relationship between child care centers' compliance with physical activity regulations and children's physical activity. Prev Chronic Dis. 2014;11, E179. doi:10.5888/pcd11.130432

* Sugiyama T, Okely AD, Masters JM, Moore GT. Attributes of child care centers and outdoor play areas associated with preschoolers' physical activity and sedentary behavior. Environment and Behavior, 2011;43(3):334. doi:10.1177/0013916510393276

Tandon PS, Saelens BE, Christakis DA. Active play opportunities at child care. Pediatrics, 2015;13(6):1425-1431. doi:10.1542/peds.2014-2750.

Timmons BW, LeBlanc AG, Carson V, et al. Systematic review of physical activity and health in the early years (aged 0-4 years). Appl Physiol Nutr Metab, 2012;37(4):773-792. 
* Trost SG, Sirard JR, Dowda M, Pfeiffer KA, Pate RR.Physical activity in overweight and non overweight preschool children. International Journal of Obesity. 2003;27(7):834-839. doi:10.1038/sj.ijo.0802311

Tucker P, van Zandvoort MM, Burke SM, Irwin JD. Physical activity at daycare: Childcare providers’ perspectives for improvements. J Early Child Res. 2011;9(3):207-219. doi:10.1177/1476718X10389144

* Van Cauwenberghe E, De Bourdeaudhuij I, Maes L, Cardon G. Efficacy and feasibility of lowering playground density to promote physical activity and to discourage sedentary time during recess at preschool: a pilot study. Prev Med. 2012;55(4):319-321. doi:10.1016/j.ypmed.2012.07.014

* Vanderloo LM, Tucker P, Johnson AM, van Zandvoort MM, Burke SM, Irwin JD. The influence of centre-based childcare on preschoolers' physical activity levels: a crosssectional study. Int J Environ Res Public Health. 2014;11(2):1794-1802. doi:10.3390/ijerph110201794

* Vanderloo LM, Tucker P, Johnson AM, Holmes JD. Physical activity among preschoolers during indoor and outdoor childcare play periods. Appl Physiol Nutr Metab. 2013;38(11):1173-1175. doi:10.1139/apnm-2013-0137

Ward DS, Vaughn A, McWilliams, C, Hales D. Interventions for increasing physical activity at child care. Med Sci Sports Exerc. 2010;42(3):526-534. oi:10.1249/MSS.0b013e3181cea406

Ward DS, Vaughn A, McWilliams C, Hales D. Physical activity at child care settings: Review and research recommendations. Am J Lifestyle Med. 2009;3(6):474-488.

* Williams HG, Pfeiffer KA, O'Neill JR, et al. Motor skill performance and physical activity in preschool children. Obesity. 2008;16(6):1421-1426. 
Figure 1 - Flow diagram of search results

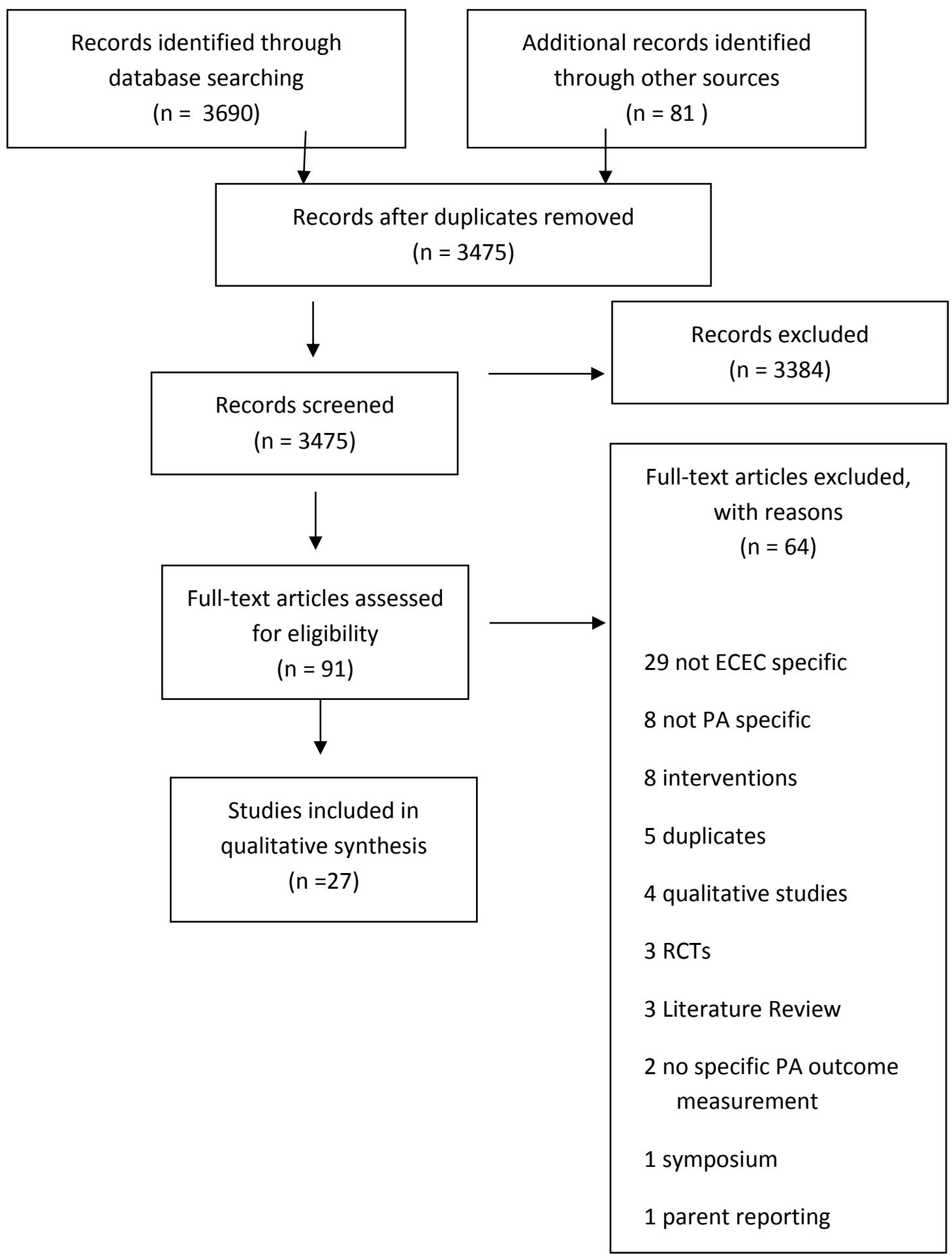


Table 1 - Rules for classifying variables regarding strength of association with children's physical activity and sedentary behavior in ECEC services

\begin{tabular}{lll}
\hline $\begin{array}{l}\text { Studies } \\
\text { supporting } \\
\text { association (\%) }\end{array}$ & $\begin{array}{l}\text { Summary } \\
\text { code }\end{array}$ & Explanation of code \\
\hline $\mathbf{0 - 3 3}$ & 0 & No association \\
$\mathbf{3 4 - 5 9}$ & $?$ & Indeterminate/inconclusive association \\
$\mathbf{6 0 - 1 0 0}$ & + & Positive association \\
\hline $\mathbf{6 0 - 1 0 0}$ & - & Negative association \\
\hline
\end{tabular}

Note: When an outcome was studied four or more times, it was coded as:

00 (no association); ?? (indeterminate); ++ (positive association); or - - (negative association). 
Table 2; Summary of Included Articles

\begin{tabular}{|c|c|c|c|c|}
\hline Author, date, location & Sample & $\begin{array}{l}\text { Physical activity / sedentary } \\
\text { behavior assessment and } \\
\text { outcome }\end{array}$ & $\begin{array}{l}\text { Correlates of physical activity } \\
\text { identified }\end{array}$ & $\begin{array}{l}\text { Social Ecological } \\
\text { Framework Domain } \\
\text { Association }\end{array}$ \\
\hline $\begin{array}{l}\text { Boldemann , Blennow, } \\
\text { Dal, Martensson, } \\
\text { Raustorp, Yuen \& } \\
\text { Wester, } 2006 \\
\text { Sweden }\end{array}$ & $\begin{array}{l}4-6 \text { year olds } \\
11 \text { preschools } \\
197 \text { children }\end{array}$ & $\begin{array}{l}\text { Pedometers (Yamax } \\
\text { Digiwalker SW-200) } \\
\text { Step count } \\
\text { TPA }\end{array}$ & $\begin{array}{l}\text { Environments with more natural features } \\
\text { Boys more active than girls } \\
\text { Older boys more active }\end{array}$ & $\begin{array}{l}\text { Child } \\
\text { Educator } \\
\text { Physical Environmental } \\
\text { Organizational }\end{array}$ \\
\hline $\begin{array}{l}\text { Bower, Hales, Tate, } \\
\text { Rubin, Benjamin \& } \\
\text { Ward, } 2008\end{array}$ & $\begin{array}{l}3-5 \text { year olds } \\
20 \text { child care centres }\end{array}$ & $\begin{array}{l}\text { OSRAP } \\
\text { TPA, sedentary \& MVPA }\end{array}$ & $\begin{array}{l}\text { Supportive environments - higher EPAO } \\
\text { scores }\end{array}$ & $\begin{array}{l}\text { Educator } \\
\text { Physical Environmental } \\
\text { Organizational }\end{array}$ \\
\hline U.S. & & & & \\
\hline $\begin{array}{l}\text { Byun, Blair \& Pate, } \\
2013 \\
\text { U.S }\end{array}$ & $\begin{array}{l}4 \text { year olds } \\
17 \text { preschools } \\
331 \text { children }\end{array}$ & $\begin{array}{l}\text { Actigraph accelerometers } \\
\text { Activity intensity } \\
\text { Sedentary }\end{array}$ & $\begin{array}{l}\text { Montessori preschools - less sedentary } \\
\text { behavior. }\end{array}$ & $\begin{array}{l}\text { Child } \\
\text { Organizational }\end{array}$ \\
\hline $\begin{array}{l}\text { Cardon, Van } \\
\text { Cauwenberghe, } \\
\text { Labarque, Haerens \& } \\
\text { De Bourdeauhuij, } 2008\end{array}$ & $\begin{array}{l}4 \& 5 \text { year olds } \\
39 \text { preschools } \\
783 \text { children }\end{array}$ & $\begin{array}{l}\text { Pedometers } \\
\text { Step count } \\
\text { TPA }\end{array}$ & $\begin{array}{l}\text { Boys more active than girls } \\
\text { Less children per } \mathrm{m}^{2} \\
\text { Shorter recess } \\
\text { Hard surface for boys } \\
\text { Less teachers present for girls }\end{array}$ & $\begin{array}{l}\text { Educator } \\
\text { Physical Environmental } \\
\text { Organizational }\end{array}$ \\
\hline Belgium & & & & \\
\hline $\begin{array}{l}\text { Dowda, Brown, } \\
\text { McIver, Pfieffer, } \\
\text { O’Neill, Addy \& Pate, } \\
2009\end{array}$ & $\begin{array}{l}3-5 \text { year old } \\
20 \text { preschools } \\
299 \text { children }\end{array}$ & $\begin{array}{l}\text { OSRAP } \\
\text { Accelerometry } \\
\text { MVPA, sedentary }\end{array}$ & $\begin{array}{l}\text { Higher quality } \\
\text { Less fixed equipment } \\
\text { More portable equipment } \\
\text { Less use of IT } \\
\text { Larger playgrounds }\end{array}$ & $\begin{array}{l}\text { Educator } \\
\text { Physical Environmental } \\
\text { Organizational }\end{array}$ \\
\hline
\end{tabular}




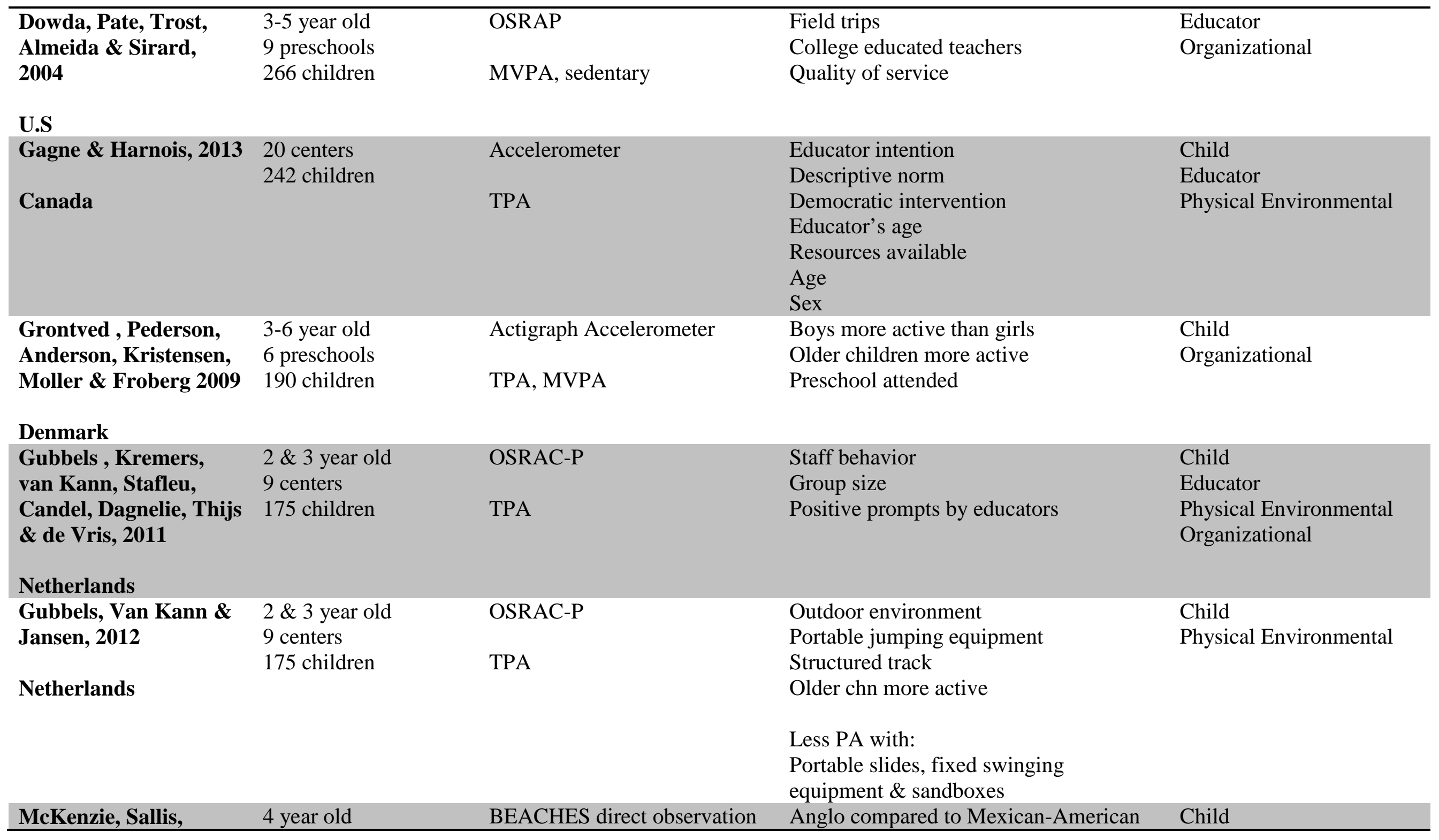




\begin{tabular}{|c|c|c|c|c|}
\hline $\begin{array}{l}\text { Nader, Broyles, \& } \\
\text { Nelson, } 1992 \\
\text { U.S }\end{array}$ & $\begin{array}{l}63 \text { preschools } \\
351 \text { children }\end{array}$ & $\begin{array}{l}\text { UNIQ heart watch (for } \\
\text { validation of observation) } \\
\text { TPA, MVPA }\end{array}$ & Boys more active than girls & Physical Environmental \\
\hline $\begin{array}{l}\text { Nicaise, Kahan \& } \\
\text { Sallis, } 2011 \\
\text { U.S }\end{array}$ & $\begin{array}{l}4 \text { \& } 5 \text { year olds } \\
51 \text { children }\end{array}$ & $\begin{array}{l}\text { OSRAC-P } \\
\text { MVPA, sedentary }\end{array}$ & $\begin{array}{l}\text { Boys more active } \\
\text { Children with normal weight more active }\end{array}$ & $\begin{array}{l}\text { Child } \\
\text { Educator } \\
\text { Physical Environmental }\end{array}$ \\
\hline $\begin{array}{l}\text { Olesen, Kristensen, } \\
\text { Korsholm \& } \\
\text { Froberg,2013 } \\
\text { Denmark }\end{array}$ & $\begin{array}{l}5 \& 6 \text { year olds } \\
42 \text { preschools } \\
426 \text { children }\end{array}$ & $\begin{array}{l}\text { Actigraph accelerometers } \\
\text { MVPA }\end{array}$ & $\begin{array}{l}\text { Motor coordination } \\
\text { Location of building } \\
\text { Sex } \\
\text { Afternoon play } \\
\text { Size of indoor play area per child } \\
\text { Less PA: } \\
\text { Preterm birth, vegetation on playground, } \\
\text { rain }\end{array}$ & $\begin{array}{l}\text { Child } \\
\text { Educator } \\
\text { Physical Environmental } \\
\text { Organizational }\end{array}$ \\
\hline $\begin{array}{l}\text { Pagels, Boldemann \& } \\
\text { Raustorp, } 2011 \\
\text { Sweden }\end{array}$ & $\begin{array}{l}3-5 \text { year olds } \\
4 \text { preschools } \\
55 \text { children }\end{array}$ & $\begin{array}{l}\text { Actigraph Accelerometers } \\
\text { Pedometers } \\
\text { Sedentary, LPA, MPA, } \\
\text { MVPA, TPA }\end{array}$ & $\begin{array}{l}\text { Age } \\
\text { Boys more active }\end{array}$ & Child \\
\hline $\begin{array}{l}\text { Pate, O’Neill, Byun, } \\
\text { McIver, Dowda \& } \\
\text { Brown, } 2014 \\
\text { U.S }\end{array}$ & $\begin{array}{l}4 \text { year old } \\
17 \text { preschools } \\
301 \text { children }\end{array}$ & $\begin{array}{l}\text { Actigraph Accelerometry } \\
\text { LPA, MVPA, TPA }\end{array}$ & $\begin{array}{l}\text { Preschool attended } \\
\text { Boys more active than girls }\end{array}$ & $\begin{array}{l}\text { Child } \\
\text { Organizational }\end{array}$ \\
\hline $\begin{array}{l}\text { Pate, McIver, Dowda, } \\
\text { Brown \& Addy, } 2008 \\
\text { U.S } \\
\text { Pate, Pfieffer, Trost, }\end{array}$ & $\begin{array}{l}3-5 \text { year olds } \\
24 \text { preschools } \\
493 \text { children }\end{array}$ & $\begin{array}{l}\text { OSRAC-P } \\
\text { Sedentary, LPA, MVPA, TPA }\end{array}$ & $\begin{array}{l}\text { Boys more active than girls } \\
3 \text { yr old boys more active than } 4-5 y r \text { olds } \\
\text { Preschool attended }\end{array}$ & Child \\
\hline
\end{tabular}




\begin{tabular}{|c|c|c|c|c|}
\hline $\begin{array}{l}\text { Ziegler \& Dowda, } 2004 \\
\text { U.S }\end{array}$ & $\begin{array}{l}9 \text { preschools } \\
281 \text { children }\end{array}$ & Sedentary, LPA, MVPA, VPA & $\begin{array}{l}\text { Boys more active than girls } \\
\text { Black chn more VPA }\end{array}$ & \\
\hline $\begin{array}{l}\text { Raustorp, Pagels, } \\
\text { Boldemann, Cosco, } \\
\text { Soderstrom \& } \\
\text { Martensson, } 2012\end{array}$ & $\begin{array}{l}3 \text { - } 5 \text { year olds } \\
4 \text { preschools } \\
50 \text { children }\end{array}$ & $\begin{array}{l}\text { Actigraph Accelerometer } \\
\text { LPA, MVPA, sedentary }\end{array}$ & $\begin{array}{l}\text { Outdoors more active } \\
\text { Sedentary greater indoors }\end{array}$ & $\begin{array}{l}\text { Physical Environmental } \\
\text { Organizational }\end{array}$ \\
\hline U.S \& Sweden & & & & \\
\hline $\begin{array}{l}\text { Robinson, Wadsworth } \\
\text { \& Peoples, } 2012 \\
\text { U.S }\end{array}$ & 34 children & $\begin{array}{l}\text { Pedometers } \\
\text { TPA }\end{array}$ & Locomotor skills & Child \\
\hline $\begin{array}{l}\text { Shen, Alexander, } \\
\text { Milberger \& Jen, } 2013 \\
\text { U.S }\end{array}$ & $\begin{array}{l}3-5 \text { years } \\
2 \text { preschools } \\
46 \text { children }\end{array}$ & $\begin{array}{l}\text { Actigraph accelerometer } \\
\text { LPA, LMVPA, MPA, VPA }\end{array}$ & Season has no influence on PA & Physical Environmental \\
\hline $\begin{array}{l}\text { Stephens, Xu, Lesesne, } \\
\text { Dunn, Kakietek, } \\
\text { Jernigan \& Khan, } 2014 \\
\text { U.S }\end{array}$ & $\begin{array}{l}2 \mathrm{yr}, 10 \mathrm{mth}-5 \mathrm{yr}, \\
11 \mathrm{mth} \\
110 \text { centers } \\
1352 \text { children }\end{array}$ & $\begin{array}{l}\text { Actigraph accelerometer } \\
\text { MVPA }\end{array}$ & $\begin{array}{l}\text { Boys more active than girls } \\
\text { Outdoor play space } \\
\text { Non-Hispanic black children more } \\
\text { MVPA than Hispanic }\end{array}$ & $\begin{array}{l}\text { Child } \\
\text { Physical Environmental }\end{array}$ \\
\hline $\begin{array}{l}\text { Sugiyama, Okely, } \\
\text { Masters \& Moore, } \\
2011 \\
\text { Australia }\end{array}$ & $\begin{array}{l}3-5 \text { years old } \\
10 \text { child care centers }\end{array}$ & $\begin{array}{l}\text { Actigraph accelerometer } \\
\text { MVPA, sedentary }\end{array}$ & $\begin{array}{l}\text { Lower staff: child ratios } \\
\text { Indoors for PA increased MVPA and } \\
\text { less sedentary } \\
\text { Fixed play equipment more MVPA, less } \\
\text { sedentary }\end{array}$ & $\begin{array}{l}\text { Educator } \\
\text { Physical Environmental } \\
\text { Organizational }\end{array}$ \\
\hline $\begin{array}{l}\text { Trost, Sirard, Dowda, } \\
\text { Pfieffer \& Pate, } 2003\end{array}$ & $\begin{array}{l}3-5 \text { year old children } \\
9 \text { preschools } \\
245 \text { children }\end{array}$ & $\begin{array}{l}\text { OSRAP } \\
\text { Accelerometer } \\
\text { TPA MVPA. VPA }\end{array}$ & Overweight boys less active & Child \\
\hline Van Cauwenberghe, & 35 preschools & Actigraph accelerometers & Less knowledge content & Child \\
\hline
\end{tabular}




\begin{tabular}{|c|c|c|c|c|}
\hline $\begin{array}{l}\text { De Bourdeaudhuij, } \\
\text { Maes \& Cardon, } 2012 \\
\text { Belgium }\end{array}$ & 573 children & $\begin{array}{l}\text { SOFIT } \\
\text { MVPA }\end{array}$ & $\begin{array}{l}\text { Less promotion } \\
\text { Less management } \\
\text { Less preschoolers per space } \\
\text { Obstruction material } \\
\text { Not using throwing equipment }\end{array}$ & $\begin{array}{l}\text { Educator } \\
\text { Physical Environmental } \\
\text { Organizational }\end{array}$ \\
\hline $\begin{array}{l}\text { Vanderloo, Tucker, } \\
\text { Johnson, van } \\
\text { Zandvoort, Burke \& } \\
\text { Irwin, } 2014 \\
\text { Canada }\end{array}$ & $\begin{array}{l}5 \text { preschools } \\
31 \text { children }\end{array}$ & $\begin{array}{l}\text { Actical Accelerometers } \\
\text { Sedentary, MVPA, TPA }\end{array}$ & $\begin{array}{l}\text { Portable equipment } \\
\text { Staff behavior }\end{array}$ & $\begin{array}{l}\text { Educator } \\
\text { Physical Environmental } \\
\text { Organizational }\end{array}$ \\
\hline $\begin{array}{l}\text { Vanderloo, Tucker, } \\
\text { Johnson, \& Holmes, } \\
2013 \\
\text { Canada }\end{array}$ & $\begin{array}{l}13 \text { preschools } \\
31 \text { children }\end{array}$ & $\begin{array}{l}\text { Actical Accelerometers } \\
\text { Sedentary, MVPA, TPA }\end{array}$ & Outdoors & Physical Environmental \\
\hline $\begin{array}{l}\text { Williams, Pfieffer, } \\
\text { O’Neill, Dowda, } \\
\text { McIver, Brown \& Pate, } \\
2008 \\
\text { U.S }\end{array}$ & $\begin{array}{l}3 \& 4 \text { year olds } \\
22 \text { preschools } \\
198 \text { children }\end{array}$ & $\begin{array}{l}\text { Actigraph accelerometer } \\
\text { Sedentary, LPA, MVPA, VPA }\end{array}$ & Locomotor skills & Child \\
\hline
\end{tabular}

LPA - light physical activity; LMPA - light to moderate physical activity; MPA - moderate physical activity; MVPA - moderate to vigorous physical activity; TPA - total physical activity; OSRAP - Observation system for recording activity in preschools; BEACHES - Behaviors of Eating and Activity for Children's Health Evaluation System ; SOFIT - System for observing fitness instruction time; OSRAC-P - Observational system for recording physical activity in children-preschool.

Note: When a Variable had no association with a SEF domain, the SEF domain was not listed. 
Table 3; Summary of Reported Correlates - Physical Activity

\begin{tabular}{|c|c|c|c|c|c|}
\hline Correlate & $\begin{array}{l}\text { Found association with } \\
\text { children's physical } \\
\text { activity in ECEC } \\
\text { service (reference) }\end{array}$ & $\begin{array}{l}\text { Association } \\
( \pm)\end{array}$ & $\begin{array}{l}\text { Found no association with } \\
\text { children's physical activity in } \\
\text { ECEC service (reference) }\end{array}$ & $\begin{array}{l}\text { Summary } \\
\text { coding for row } \\
\text { (n/N for row; } \\
\%) \\
\end{array}$ & $\begin{array}{l}\text { Summary code } \\
\text { for association } \\
(-/+)\end{array}$ \\
\hline \multicolumn{6}{|l|}{ CHILD VARIABLES } \\
\hline Age of child & $\begin{array}{l}\text { (Older) } \\
\text { Gagne \& Harnois, 2013, } \\
\text { Gubbels et al., 2012, } \\
\text { Pagels et al., 2011, } \\
\text { Gubbels et al., 2011 } \\
\text { Grontved et al., 2009, } \\
\text { Boldemann et al., 2006 } \\
\text { (Younger) } \\
\text { Stephens et al., 2014 } \\
\text { Shen et al., 2013 }\end{array}$ & + & $\begin{array}{l}\text { Olesen et al., 2013, } \\
\text { Gubbels et al., 2011 } \\
\text { Pate et al., } 2004^{\mathrm{u}}\end{array}$ & $8 / 11$ (73) & ++ \\
\hline BMI / Adiposity & $\begin{array}{l}\text { Robinson et al., 2012, } \\
\text { Nicaise et al., 2011, } \\
\text { Trost et al., } 2003^{\mathrm{f}}\end{array}$ & - & $\begin{array}{l}\text { Byun et al., 2013, } \\
\text { Olesen et al., 2013, } \\
\text { Trost et al., 2003 }\end{array}$ & $3 / 6(50)$ & ?? \\
\hline Motor coordination & $\begin{array}{l}\text { Olesen et al., 2013, } \\
\text { Robinson et al., 2012, } \\
\text { Williams et al., } 2008\end{array}$ & + & Williams et al., $2008^{\mathrm{h}}$ & $3 / 4(75)$ & ++ \\
\hline Sex & $\begin{array}{l}\text { Stephens et al., 2014 } \\
\text { Pate et al., 2014, } \\
\text { Byun et al., 2013, } \\
\text { Gagne \& Harnois, 2013, } \\
\text { Olesen et al., 2013, } \\
\text { Van Cauwenberghe et } \\
\text { al., 2012 }\end{array}$ & + & $\begin{array}{l}\text { Robinson et al., 2012, } \\
\text { Gubbels et al., 2011, } \\
\text { Pate et al., 2008 } \\
\text { Pate et al., 2004 }\end{array}$ & 14/18 (78) & ++ \\
\hline
\end{tabular}




\begin{tabular}{|c|c|c|c|c|c|}
\hline & $\begin{array}{l}\text { Nicaise et al., 2011, } \\
\text { Pagels et al., 2011, } \\
\text { Grontved et al., 2009, } \\
\text { Pate et al., 2008, } \\
\text { Pate et al., 2008 }{ }^{\mathrm{u}} \text {, } \\
\text { Boldemann et al., 2006, } \\
\text { Pate et al., 2004 }{ }^{\mathrm{u}} \\
\text { McKenzie et al., } 1992\end{array}$ & & & & \\
\hline Born pre term & Olesen et al., 2013 & - & & $1 / 1(100)$ & - \\
\hline Ethnicity & $\begin{array}{l}\text { Stephens et al., 2014 } \\
\text { Byun et al., 2013, } \\
\text { Pate et al., 2004', } \\
\text { McKenzie et al.,1992 }\end{array}$ & + & $\begin{array}{l}\text { Olesen et al., } 2013 \\
\text { Pate et al., } 2008^{\mathrm{v}} \text {, } \\
\text { Pate et al., } 2004^{\mathrm{v}}\end{array}$ & 4/7 (57) & ?? \\
\hline Parent Education & Olesen et al., 2013 & + & $\begin{array}{l}\text { Byun et al., 2013, } \\
\text { Pate et al., } 2008^{w}\end{array}$ & 1/3 (33) & ? \\
\hline Attendance Rates & Boldemann et al., 2006 & + & & $1 / 1(100)$ & + \\
\hline Peer prompts (response to) & Gubbels et al., 2011 ${ }^{\mathrm{e}}$ & + & Gubbels et al., 2011 ${ }^{\mathrm{d}}$ & $1 / 2(50)$ & ? \\
\hline \multicolumn{6}{|l|}{ EDUCATOR VARIABLES } \\
\hline Age of educator & Gagne \& Harnois, 2013 & + & & $1 / 1(100)$ & + \\
\hline \multicolumn{6}{|l|}{ Educator Influences } \\
\hline $\begin{array}{l}\text { Educator intention } \\
\text { \& belief }\end{array}$ & Gagne \& Harnois, 2013 & + & & $1 / 1(100)$ & + \\
\hline $\begin{array}{l}\text { Educator confidence } \\
\text { \& enjoyment }\end{array}$ & & & $\begin{array}{l}\text { Gagne \& Harnois 2013, } \\
\text { Olesen et al., } 2013\end{array}$ & $0 / 2(0)$ & 0 \\
\hline
\end{tabular}




\begin{tabular}{|c|c|c|c|c|c|}
\hline $\begin{array}{l}\text { Educator behaviors } \\
\text { (prompts, feedback) }\end{array}$ & $\begin{array}{l}\text { Gagne \& Harnois, 2013, } \\
\text { Gubbels et al., 2011, } \\
\text { Boldemann et al., } 2006\end{array}$ & + & $\begin{array}{l}\text { Vanderloo et al., } 2014 \\
\text { Dowda et al., } 2009^{\text {b }} \\
\text { Bower et al., } 2008\end{array}$ & $3 / 7(43)$ & ?? \\
\hline & $\begin{array}{l}\text { Van Cauwenberghwe et } \\
\text { al., } 2012\end{array}$ & - & & & \\
\hline \multirow[t]{2}{*}{$\begin{array}{l}\text { Educator Qualifications \& } \\
\text { Training }\end{array}$} & $\begin{array}{l}\text { Van Cauwenberghe et } \\
\text { al., 2012 } \\
\text { Nicaise et al., } 2011 \text {, } \\
\text { Sugiyama et al., } 2011\end{array}$ & + & $\begin{array}{l}\text { Dowda et al., 2009 } \\
\text { Bower et al., 2008, } \\
\text { Cardon et al., 2008 } \\
\text { Dowda et al., 2004 }\end{array}$ & 3/8 (38) & ?? \\
\hline & $\begin{array}{l}\text { Van Cauwenberghe et } \\
\text { al., } 2012^{\text {b }}\end{array}$ & - & & & \\
\hline \multicolumn{6}{|l|}{ Social Environment } \\
\hline $\begin{array}{l}\text { Solitary } \\
\text { environment }\end{array}$ & Nicaise et al., 2011 & + & & $1 / 1(100)$ & + \\
\hline Peers present & $\begin{array}{l}\text { Nicaise et al., } 2011^{\mathrm{t}} \text {, } \\
\text { Gubbels et al., } 2011\end{array}$ & + & $\begin{array}{l}\text { Nicaise et al., } 2011 \text { (>1 peer), } \\
\text { Gubbels et al., } 2011^{\mathrm{t}}\end{array}$ & $2 / 4(50)$ & ?? \\
\hline \multirow[t]{2}{*}{ Educator present } & $\begin{array}{l}\text { Gubbels et al., } 2011^{\mathrm{d}} \text {, } \\
\text { Sugiyama et al., } 2011^{\text {b }}\end{array}$ & + & $\begin{array}{l}\text { Nicaise et al., 2011, } \\
\text { Gubbels et al., 2011 } \\
\text { Cardon et al.,2008 }\end{array}$ & 2/6 (33) & 00 \\
\hline & Cardon et al., 2008 & - & & & \\
\hline \multicolumn{6}{|l|}{$\begin{array}{l}\text { PHYSICAL } \\
\text { ENVIRONMENTAL } \\
\text { VARIABLES }\end{array}$} \\
\hline \multicolumn{6}{|l|}{ Environment } \\
\hline Sedentary items & & & $\begin{array}{l}\text { Bower et al., 2008, } \\
\text { Bower et al., 2008 }\end{array}$ & $0 / 2(0)$ & 0 \\
\hline
\end{tabular}




\begin{tabular}{|c|c|c|c|c|c|}
\hline $\begin{array}{l}\text { Indoor environments } \\
\text { (relationship to } \\
\text { physical activity) }\end{array}$ & & & $\begin{array}{l}\text { Gagne et al., 2013, } \\
\text { Vanderloo et al., 2013, } \\
\text { Olesen et al., } 2013\end{array}$ & $0 / 3(0)$ & 0 \\
\hline $\begin{array}{l}\text { Outdoor } \\
\text { environments } \\
\text { (relationship to } \\
\text { physical activity) }\end{array}$ & $\begin{array}{l}\text { Raustorp et al., 2012 } \\
\text { Stephens et al., 2014 } \\
\text { Vanderloo et al., 2013, } \\
\text { Vanderloo et al., 2013 } \\
\text { Vanderloo et al., } 2013^{\mathrm{x}} \text {, } \\
\text { Vanderloo et al., 2013 }\end{array}$ & + & Vanderloo et al., 2013 & $6 / 7(86)$ & ++ \\
\hline $\begin{array}{l}\text { Size of play space } \\
\text { (total area of the } \\
\text { outdoor environment, } \\
\mathbf{m}^{2} \text { ) }\end{array}$ & $\begin{array}{l}\text { Dowda et al., 2009 } \\
\text { Nicaise et al., 2011, } \\
\text { Boldemann et al., 2006, } \\
\text { Gubbels et al., } 2011\end{array}$ & + & $\begin{array}{l}\text { Olesen et al., 2013, } \\
\text { Sugiyama et al., 2011 }\end{array}$ & $4 / 6(67)$ & ++ \\
\hline $\begin{array}{l}\text { Natural features / } \\
\text { surface }\end{array}$ & $\begin{array}{l}\text { Nicaise et al., 2011, } \\
\text { Olesen et al., 2013, }\end{array}$ & + & $\begin{array}{l}\text { Cardon et al., 2008, } \\
\text { Sugiyama et al., } 2011\end{array}$ & $2 / 5(40)$ & ?? \\
\hline & Sugiyama et al., 2011b & - & & & \\
\hline Gradient & Olesen et al., 2013 & + & Sugiyama et al., 2011 & $1 / 2(50)$ & ? \\
\hline Shade & & & Sugiyama et al., 2011 & $0 / 1(0)$ & 0 \\
\hline Markings & & & Cardon et al., 2008 & $0 / 1(0)$ & 0 \\
\hline \multicolumn{6}{|l|}{ Equipment } \\
\hline Portable equipment & $\begin{array}{l}\text { Dowda et al., 2009, } \\
\text { Nicaise et al., 2011 } \\
\text { Vanderloo et al., } 2014^{\mathrm{b}} \text {, } \\
\text { Gubbels et al., } 2012^{\mathrm{m}} \text {, } \\
\text { Van Cauwenberghe et } \\
\text { al., 2012 }\end{array}$ & + & $\begin{array}{l}\text { Bower et al., 2008, } \\
\text { Bower et al., 2008, } \\
\text { McKenzie et al., 1992, } \\
\text { Gagne et al., 2013, } \\
\text { Vanderloo et al., 2014, } \\
\text { Cardon et al., 2008, } \\
\text { Olesen et al., 2013 }\end{array}$ & 5/13 (38) & ?? \\
\hline
\end{tabular}




\begin{tabular}{|c|c|c|c|c|c|}
\hline & $\begin{array}{l}\text { Van Cauwenberghe et } \\
\text { al., } 2012^{\mathrm{j}}\end{array}$ & - & & & \\
\hline Fixed equipment & $\begin{array}{l}\text { Dowda et al., 2009 } \\
\text { Nicaise et al., 2011, } \\
\text { Gubbels et al., 2012 } \\
\text { Sugiyama et al., } 2011^{\mathrm{b}} \\
\text { Vanderloo et al., 2014 }\end{array}$ & + & $\begin{array}{l}\text { Bower et al., 2008, } \\
\text { Bower et al., 2008 } \\
\text { Vanderloo et al., 2014, } \\
\text { Cardon et al., 2008, } \\
\text { Olesen et al., 2013 }\end{array}$ & $4 / 10(40)$ & ?? \\
\hline Height of equipment & & & Cardon et al., 2008 & $0 / 1(0)$ & 0 \\
\hline Weather & Olesen et al., 2013 & + & Shen et al., 2013 & $1 / 2(50)$ & ? \\
\hline \multicolumn{6}{|l|}{$\begin{array}{l}\text { ORGANIZATIONAL } \\
\text { VARIABLES }\end{array}$} \\
\hline \multicolumn{6}{|l|}{ Opportunities } \\
\hline $\begin{array}{l}\text { Active opportunities } \\
\text { (eg, recess, indoor } \\
\text { space for } P A)\end{array}$ & $\begin{array}{l}\text { Bower et al., } 2008 \\
\text { Bower et al., 2008 } \\
\text { Cardon et al., 2008, } \\
\text { Sugiyama et al., 2011 }\end{array}$ & + & Dowda et al., $2009^{b}$ & $4 / 5(80)$ & ++ \\
\hline $\begin{array}{l}\text { Sedentary } \\
\text { opportunities } \\
\text { (eg, sitting at group } \\
\text { time) }\end{array}$ & & & $\begin{array}{l}\text { Bower et al., 2008, } \\
\text { Bower et al., 2008 } \\
\text { Vanderloo et al., } 2014^{\mathrm{b}}\end{array}$ & $0 / 3(0)$ & 0 \\
\hline Physical Activity Policy & & & $\begin{array}{l}\text { Bower et al., 2008, } \\
\text { Bower et al., 2008b, } \\
\text { Olesen et al., } 2013\end{array}$ & $0 / 3(0)$ & 0 \\
\hline $\begin{array}{l}\text { Service Quality } \\
(e g, E P A O, E C E R S-R)\end{array}$ & $\begin{array}{l}\text { Dowda et al., } 2009^{\mathrm{b}} \text {, } \\
\text { Bolemann et al., } 2006 \text {, } \\
\text { Gubbels et al., } 2011\end{array}$ & + & $\begin{array}{l}\text { Bower et al., 2008, } \\
\text { Bower et al., 2008 } \\
\text { Dowda et al., } 2004^{\text {b }}\end{array}$ & $3 / 6(50)$ & ?? \\
\hline Preschool Location & Raustorp et al., $2012^{\mathrm{bb}}$ & + & $\begin{array}{l}\text { Raustorp et al., } 2012^{\mathrm{cc}} \text {, } \\
\text { Raustorp et al., } 2012^{\text {dd }}\end{array}$ & 1/6 (17) & 0 \\
\hline
\end{tabular}




\begin{tabular}{|c|c|c|c|c|c|}
\hline & & & $\begin{array}{l}\text { Raustorp et al., } 2012^{\mathrm{ee}} \text {, } \\
\text { Raustorp et al., } 2012^{\mathrm{ff}} \text {, } \\
\text { Grontved et al., } 2009\end{array}$ & & \\
\hline \multicolumn{6}{|l|}{ Program Type } \\
\hline Preschool type & $\begin{array}{l}\text { Byun et al., } 2013 \\
\text { (Montessori), } \\
\text { Pate et al., } 2014 \\
\text { (Montessori) }\end{array}$ & + & $\begin{array}{l}\text { Byun et al., } 2013 \text { (private), } \\
\text { Dowda et al., } 2004^{\text {b }} \\
\text { Olesen et al., } 2013\end{array}$ & $2 / 5(40)$ & ?? \\
\hline Group size & $\begin{array}{l}\text { Cardon et al., } 2008 \\
\text { (child: educator ratio), } \\
\text { Dowda et al., 2009, } \\
\text { Van Cauwenberghe et } \\
\text { al., } 2012 \text { (child: educator } \\
\text { ratio) }\end{array}$ & + & $\begin{array}{l}\text { Dowda } 2009^{\mathrm{b}}, \\
\text { Dowda et al., } 2004^{\mathrm{b}} \text {, } \\
\text { Olesen et al., } 2013 \text {, } \\
\text { Sugiyama et al., } 2011\end{array}$ & 3/7 (43) & ?? \\
\hline Field trips & Dowda et al., $2004^{\text {b }}$ & + & $\begin{array}{l}\text { Dowda et al., } 2009^{b} \text {, } \\
\text { Olesen et al., } 2013\end{array}$ & 1/3 (33) & 0 \\
\hline Time spent outside & & & $\begin{array}{l}\text { Dowda et al., } 2009^{\mathrm{b}} \text {, } \\
\text { Dowda et al., } 2004^{\mathrm{b}} \text {, } \\
\text { Olesen et al., } 2013\end{array}$ & $0 / 3(0)$ & 0 \\
\hline Electronic media & Dowda et al., 2009 & - & $\begin{array}{l}\text { Dowda et al., 2004, } \\
\text { Olesen et al., } 2013\end{array}$ & 1/3 (33) & 0 \\
\hline Free time & & & Dowda et al., 2004 & 0/1 (0) & $\mathbf{0}$ \\
\hline
\end{tabular}

a-Light activity; b- MVPA; c- VPA; d- indoor; e- outdoor; f- boys; g- girls; h-3yr olds; j-throwing equipment ; k-equipment with wheels; l-obstruction equipment; mriding toys; n-jumping; p-slides; q-structured track; r-sandbox; s-swinging equipment; $t$-1 peer; u-MVPA \& VPA; v-Light activity \& MVPA; w-Light, MVPA \& VPA; $x$ MVPA \& boys; y-MVPA \& girls; z-MVPA, throwing equipment \& equipment with wheels; aa-jumping, slides, structured track, sandbox \& swinging equipment; bb-Light activity \& indoor; cc-MVPA \& indoor; dd-MVPA \& outdoor; ee-Light activity \& outdoor; ff-boys \& girls

+positive ass; ++positive ass for 4 or more studies; -negative ass; 0 no ass; 00 no ass for 4 or more studies; ?indeterminate/inconclusive; ?? indeterminate/inconclusive for 4 or more studies

Note: When no note is used, this refers to total Physical Activity (light, moderate and vigorous intensity)

Note: Some studies presented multiple variables within the results (such as child age in relation to indoor as well as outdoor environments). When this occurred the reference was counted multiple times in the association column and the specific variable(s) measured indicated with a footnote. 
Table 4; Summary of Reported Correlates - Sedentary Behavior

\begin{tabular}{|c|c|c|c|c|c|}
\hline Correlate & $\begin{array}{l}\text { Found association with } \\
\text { children's sedentary } \\
\text { behavior in ECEC service } \\
\text { (reference) }\end{array}$ & $\begin{array}{l}\text { Association } \\
( \pm)\end{array}$ & $\begin{array}{l}\text { Found no association with } \\
\text { children's sedentary behavior in } \\
\text { ECEC service (reference) }\end{array}$ & $\begin{array}{l}\text { Summary } \\
\text { coding for row } \\
(\mathbf{n} / \mathbf{N} \text { for row; } \\
\%) \\
\end{array}$ & $\begin{array}{l}\text { Summary } \\
\text { code for } \\
\text { associatio } \\
\text { n }(-/+) \\
\end{array}$ \\
\hline \multicolumn{6}{|l|}{ CHILD VARIABLES } \\
\hline Age & Byun et al., 2013 & + & & $1 / 1(100)$ & + \\
\hline Sex & Byun et al., 2013 & + & $\begin{array}{l}\text { Pate et al., 2008, } \\
\text { Pate et al., 2004 }\end{array}$ & 1/3 (33) & ? \\
\hline Ethnicity & Byun et al., 2013 & + & $\begin{array}{l}\text { Pate et al., 2008, } \\
\text { Pate et al., 2004 }\end{array}$ & 1/3 (33) & ? \\
\hline Parent Education & & & $\begin{array}{l}\text { Byun et al., 2013, } \\
\text { Pate et al., } 2004\end{array}$ & $0 / 2(0)$ & 0 \\
\hline \multicolumn{6}{|l|}{ EDUCATOR VARIABLES } \\
\hline Educator Training \& Qualifications & & & $\begin{array}{l}\text { Bower et al., 2008, } \\
\text { Dowda et al., 2009, } \\
\text { Dowda et al., 2004, } \\
\text { Sugiyama et al., 2011 }\end{array}$ & $0 / 4(0)$ & 0 \\
\hline Educator Behaviors & & & $\begin{array}{l}\text { Bower et al., 2008, } \\
\text { Dowda et al., } 2009\end{array}$ & $0 / 2(0)$ & 0 \\
\hline
\end{tabular}

\section{Environment}

\begin{tabular}{lccc} 
Sedentary items & Bower et al., 2008 & 0 \\
& Vanderloo et al., 2013 & $0)$ & $0 / 1(0)$ \\
\hline Indoor environments & Van & 0 \\
\hline
\end{tabular}




\begin{tabular}{|c|c|c|c|c|c|}
\hline Outdoor environments & $\begin{array}{l}\text { Pate et al., 2004, } \\
\text { Vanderloo et al., 2013, } \\
\text { Vanderloo et al., 2014 }\end{array}$ & - & Vanderloo et al., $2014^{\mathrm{g}}$ & $3 / 4(75)$ & -- \\
\hline $\begin{array}{l}\text { Size of play space } \\
\text { (total area of the outdoor } \\
\text { environment, } \mathrm{m}^{2} \text { ) }\end{array}$ & Dowda et al., 2009 & - & Sugiyama et al., 2011 & $1 / 2(50)$ & $?$ \\
\hline Natural features / surface & & & Sugiyama et al., 2011 & $0 / 1(0)$ & 0 \\
\hline Gradient & & & Sugiyama et al., 2011 & $0 / 1(0)$ & 0 \\
\hline Shade & & & Sugiyama et al., 2011 & $0 / 1(0)$ & 0 \\
\hline \multicolumn{6}{|l|}{ Equipment } \\
\hline Portable equipment & Dowda et al., 2009 & - & Bower et al., 2008 & $1 / 2(50)$ & ? \\
\hline \multirow[t]{2}{*}{ Fixed equipment } & Dowda et al., 2009 & + & Bower et al., 2008 & $1 / 3(33)$ & 0 \\
\hline & Sugiyama et al., 2011 & - & & & \\
\hline \multicolumn{6}{|l|}{$\begin{array}{l}\text { ORGANIZATIONAL / POLICY } \\
\text { VARIABLES }\end{array}$} \\
\hline \multicolumn{6}{|l|}{ Opportunities } \\
\hline $\begin{array}{l}\text { Active opportunities } \\
\text { (eg, recess, indoor space for } P A)\end{array}$ & $\begin{array}{l}\text { Bower et al., 2008, } \\
\text { Sugiyama et al., 2011 }\end{array}$ & - & Dowda et al., 2009 & $2 / 3(66)$ & - \\
\hline $\begin{array}{l}\text { Sedentary opportunities } \\
\text { (eg, sitting at group time) }\end{array}$ & & & Bower et al., 2008 & $0 / 1(0)$ & 0 \\
\hline Physical Activity Policy & & & Bower et al., 2008 & $0 / 1(0)$ & 0 \\
\hline Service Quality & Dowda et al., 2009, & - & Bower et al., 2008 & $2 / 3(66)$ & - \\
\hline
\end{tabular}




\begin{tabular}{|c|c|c|c|c|c|}
\hline$(e g, E P A O, E C E R S-R)$ & Dowda et al., 2004 & & & & \\
\hline Preschool Location & $\begin{array}{l}\text { Raustorp et al., } 2012^{\mathrm{d}} \\
\text { (Sweden) }\end{array}$ & - & Raustorp et al., $2012^{\mathrm{e}}$ & $1 / 2(50)$ & ? \\
\hline \multicolumn{6}{|l|}{ Program Type } \\
\hline Preschool type & $\begin{array}{l}\text { Byun et al., } 2013 \\
\text { (Montessori) }\end{array}$ & - & & $1 / 1(100)$ & - \\
\hline Group size & & & $\begin{array}{l}\text { Dowda et al., } 2009 \text { (child: educator } \\
\text { ratio), } \\
\text { Dowda et al., } 2004\end{array}$ & $0 / 2(0)$ & 0 \\
\hline Field trips & & & $\begin{array}{l}\text { Dowda et al., 2009, } \\
\text { Dowda et al., } 2004\end{array}$ & $0 / 2(0)$ & 0 \\
\hline Time spent outside & & & $\begin{array}{l}\text { Dowda et al., 2009, } \\
\text { Dowda et al., } 2004\end{array}$ & $0 / 2(0)$ & 0 \\
\hline Electronic media & Dowda et al., 2009 & + & Dowda et al., 2004 & $1 / 2(50)$ & ? \\
\hline Free time & & & Dowda et al., 2004 & $0 / 1(0)$ & 0 \\
\hline
\end{tabular}

d- Indoor; e- Outdoor; f- Boys; g- Girls; +positive ass; -negative ass; 0 no ass; ?indeterminate/inconclusive;

When no note is used, this refers to total sedentary behavior.

Note: Some studies presented multiple variables within the results (such as preschool location in relation to indoor as well as outdoor environments). When this occurred the reference was counted multiple times in the association column and the specific variable(s) measured indicated with a footnote. 